\title{
Efficiency of Corporate Income Tax Reliefs for the Investment Promotion in Latvia
}

\author{
Ilmārs Šnucins, University of Latvia
}

\begin{abstract}
Corporate income tax rate in Latvia is one of the lowest in the European Union and is favourable for business. However, the government additionally uses numerous CIT reliefs to stimulate investments, to promote specific industries and investors. Total costs of these tax reliefs are high, but many of the goals declared by their introduction are not reached, suggesting that tax relief efficiency could be questioned. The efficiency of the existing and potential CIT reliefs should be regularly evaluated. The suggested criteria for such examination are - clear objective, type of taxable rent, existence of positive externality, appropriate design and potential for tax planning, costs in revenue foregone, administrative burden.
\end{abstract}

Keywords: tax reliefs, investments, corporate income tax

\section{INTRODUCTION}

Corporate income tax (CIT) is generally seen as one of the main obstacles to investments, but the revenue from CIT are important to the governments. Therefore, to get positive externalities from investments, it is possible to use different tax reliefs aimed at particular investment activities, sectors or regions, maintaining a higher standard tax rate.

In Latvia, statutory CIT rate is low - flat $15 \%$, and the existing tax reliefs decrease an implicit tax rate even below $10 \%$ showing their importance.

The aims of the paper are to substantiate CIT reliefs, to analyse effectiveness of the existing CIT reliefs in order to promote investments in Latvia and to make recommendations in order to improve the situation. The research methodology is based on the studies of economic and scientific literature, national legislation, analysis of statistical macroeconomic and tax data.

The article focuses only on investment related to CIT reliefs. The author proposes a set of criteria appropriate for the evaluation of CIT investments related to reliefs in Latvia.

\section{THEORETICAL CONSIDERATIONS}

Corporate income tax is common in most tax systems in the world. Like all taxes, also CIT brings some distortions to the economy. It taxes corporate profit and directly affects investment decisions and capital flows by influencing after-tax rates of return on investment. Corporate income tax is also at the forefront of international tax competition, since the capital is the most mobile factor of production.

In many countries, CIT is an important source of revenue, and governments are not ready to lose it by abolishing CIT in favour of potential investments. Moreover, empirical evidence suggests that effective management of public expenditure (e.g., education, infrastructure etc.) and the rule of law can more than compensate for this tax burden.

Investors are also ready to accept higher taxes if risk/return opportunities are more attractive. [2, pp.105-108] In the presence of economic rents, it may be possible to levy high capital taxes. It is important, however, to distinguish the types of rents. Only firm-specific rents are subject to full tax competition. In taxation of location-specific rents, it is more important that taxes are proportional to the rent [3].

Rate of corporate income tax, however, is declining throughout the world and in the European Union in particular. This could be explained by the growing role of mobile capital flows in the global economy and tax competition for them. To limit negative fiscal consequences, it is possible to use different tax reliefs that offer smaller payments to particular activities, but do not influence the rest of tax base.

One of the main goals for introducing tax reliefs is to produce incentives for investment attraction in order to boost economic growth. However, it is often done under pressure of international tax competition to limit outflow of investments. Another broad group of tax reliefs are those where governments expect positive externalities by stimulating specific investments.

Examples could be incentives for R\&D expenditures or incentives to invest in particular regions or sectors.

CIT reliefs are widely used as a tool to boost investment, to increase output, and to improve the competitive position of a country especially in the future, but they can have also shortterm consequences since investment spending is an important component of GDP. However, it is important to stress that an effective tax rate is only one of the factors influencing investment decisions.

Main alternative to tax reliefs usually is direct government spending, but the use of tax reliefs has many positive aspects int. al. encouraging private sector participation in programmes, where the government plays a main role, promoting private decision-making and reducing the need for close government supervision of such spending [4, 3].

On the government side, costs and other possible negative aspects of tax reliefs should be taken into consideration as well. Main possible drawbacks are the following:

- ineffectiveness, since some tax reliefs are insufficient to override underlying economic forces or are offset by other domestic or foreign tax provisions; - inefficiency, since many tax reliefs are a response to various interest groups rather than to actual needs, unreasonably altering relative profitability of some projects [4, 4].

\section{INVESTMENT RELATED CIT RELIEFS IN LATVIA}

In Latvia, a corporate income tax rate of $15 \%$ is one the lowest in the EU. The law contains 23 tax reliefs, thus, considerably decreasing an effective tax rate. According to the calculation of the European Commission, the implicit tax rate 
(ITR) on business income of corporations in Latvia in 2010 was even $4.1 \%$. However, average ITR has been $8.3 \%$ since 2004. [1, p.261]

Nine of CIT reliefs are attributable to the promotion of investments. Additionally, six tax reliefs are aimed at supporting specific industries [5].

\section{A. Tax Reliefs to Promote Investments}

- Accelerated depreciation of fixed assets (Section 13, paragraph 1, item 3 of Law on CIT) ${ }^{1}$.

The amount of depreciation of fixed assets is calculated applying double the rate of depreciation prescribed for the relevant category of fixed assets. Tax relief was introduced in 1995.

- Covering Losses of Previous Years and Transfer of Losses to a Group of Undertakings (Section 14 and 141 of Law on CIT).

If the adjustment of profit or loss of a taxation period of a taxpayer results in losses, these losses may be covered in a chronological sequence from taxable income of the next taxation periods. Tax relief was introduced in 1995 .

If a participant in a group of undertakings has losses, taxable income of the same taxation period of other participants in such a group of undertakings may be reduced by the amount which, taken altogether, does not exceed the amount of losses of the first referred to undertaking. Tax relief was introduced in 1997.

- Tax relief for investments in Free Ports and Special Economic Zones (Chapter III of Law on the Application of Taxes in Free Ports and Special Economic Zones).

A zone capital company or a licensed capital company is entitled to apply corporate income tax rebate in the amount up to 80 per cent of the tax amount calculated if conditions stipulated in the law are fulfilled. Tax relief was introduced in 1997 and will expire in 2017.

- Tax relief for the acquisition of fixed assets in territories with the status of a territory requiring special assistance (Section 13, paragraph 1, item 9 of Law on CIT).

A taxpayer, which is registered and operating in a territory requiring special assistance specified in accordance with the Regional Development Law, may increase the value of the fixed assets, which were acquired in the time period commencing with such taxation period while the relevant territory had the status of a territory requiring special assistance and which are used in economic activity in such territory, prior to calculation of the total amount of depreciation of the relevant category of fixed assets in the taxation period, by multiplying such by the coefficients $1.3-2$ depending on the category of fixed assets. Tax relief

\footnotetext{
${ }^{1}$ For a full definition and application of tax reliefs see Law on Corporate Income Tax, descriptions in this paper are given for illustrative purposes only.
}

was introduced in 1997; the supported territories are defined every 3 years.

- Tax relief for the acquisition of new production technology equipment (Section 13, paragraph $1^{1}$ of Law on CIT).

Prior to the calculation of the amount of depreciation in a taxation period, the value of new production technology equipment shall be multiplied by the coefficient 1.5. Tax relief was introduced in 2006 and will expire in 2013.

- Allowance for corporate equity (Section 6, paragraph 17 of Law on CIT).

Tax relief allows the taxpayer to reduce the profit for the multiplication of the annual weighted interest rate of the credit granted in LVL to domestic non-financial enterprises and undistributed profit of pre-taxation periods. Tax relief was introduced in 2009.

- Tax relief for income obtained in case of replacement of fixed assets (Section 101 of Law on CIT).

The taxable income may be reduced by income from alienation of fixed assets, if a functionally similarly applicable fixed asset is acquired within 12 months prior to or after the date of the alienation. Tax relief was introduced in 2009.

- Tax relief for research and development (Section 13, paragraph 41 of Law on CIT).

Prior to writing-off the costs of the establishment or acquisition of those intangible investments as a result of which a trademark or a patent has been registered, the value of the establishment or acquisition of those investments shall be increased by multiplying with coefficient 1.5. Tax relief was introduced in 2009.

- Tax relief for investments made within the scope of supported investment projects (Section 172 of Law on CIT).

Tax rebate applies to initial investments in the supported investment project. If investment amount is between 3 and $35 \mathrm{mln} \mathrm{LVL}$, than tax rebate is $25 \%$, if it exceeds $35 \mathrm{mln}$ LVL - 15\%. Only enterprises in 16 priority industries can apply for this relief. Tax relief was introduced in 2011 and will expire in 2016.

\section{B. Tax Reliefs to Support Specific Industries}

- Tax rebate for agriculture (Section 18 of Law on CIT).

A taxpayer carrying out agricultural activities can use tax rebate in the amount of $10 \mathrm{LVL}$ for each hectare of usable agricultural land. Tax relief was introduced in 1995.

- Inclusion in taxable income of reserves created by banks and savings and loan societies and provided for debts of debtors (Section 7 of Law on CIT); funds provided for technical reserves of insurance and reinsurance companies (Section 8 of Law on CIT).

Taxable income shall not be increased for banks and savings and loan societies by such amount of 
deductions, by which the expenditures for reserves provided for debts of debtors are recognised in the taxation period, and shall not be reduced by the amount, by which the reserves (reversed expenditures recognised in the previous taxation periods) created for debts of debtors in accordance with the procedures for creation of reserves provided for in regulatory enactments of the Finance and Capital Market Commission are reduced in the taxation period. Taxable income of insurance and reinsurance companies shall not be increased by such amount of deductions, which has been included in technical reserves, and shall not be reduced by the amount withdrawn from such reserves and included in the income in accordance with the Law On Insurance Companies and their Supervision or the Law on Reinsurance. Tax reliefs were introduced in 1995.

- Tax relief for agriculture (Section 6, paragraph 4, item 2 of Law on CIT).

In determining taxable income, the profit of a taxpayer is decreased by the amounts paid in the form of subsidies as state aid to agriculture or the European Union aid to agriculture and rural development. Tax relief was introduced in 1996.

- Tax relief to financial intermediation industry for stock trading (Section 6, paragraph 1, item 8 and paragraph 4, item 9 of Law on CIT).

Taxable income of a taxpayer shall be increased by the expenditures, which are related to the acquisition of stocks in the taxation period. In determining taxable income, the profit of a taxpayer shall be decreased by income from the sale of stocks. Tax relief was introduced in 1998, but considerably broadened in 2004 and 2012.

- Tax relief for the shipping industry (Section 21 of Law on CIT).

A tonnage tax regime is an option allowing companies registered in Latvia to have their taxable profits from certain shipping activities determined at fixed income rates based on the "net tonnage" of the ship(s) used in these activities rather than the actual business results from using the $\operatorname{ship}(\mathrm{s})$. Tax relief was introduced in 2002.

- Tax relief for the aviation industry (Section 3, paragraph 46 of Law on CIT).

It is tax relief to payments for the lease of aircraft used in international air traffic. Tax relief was introduced in 2009.

\section{EFFECTIVENESS}

Overall CIT burden in Latvia is low and competitive in the region. The implicit tax rate on capital and business income of corporations in Latvia is among the lowest in the EU and is comparable to other Baltic countries.

Also study of the taxation of mid-sized firm that is adjusted by the level of GNI per capita shows that Latvia's position is favourable for both - start-ups and mature firms compared to the other countries in Baltic Sea Region and CEE.

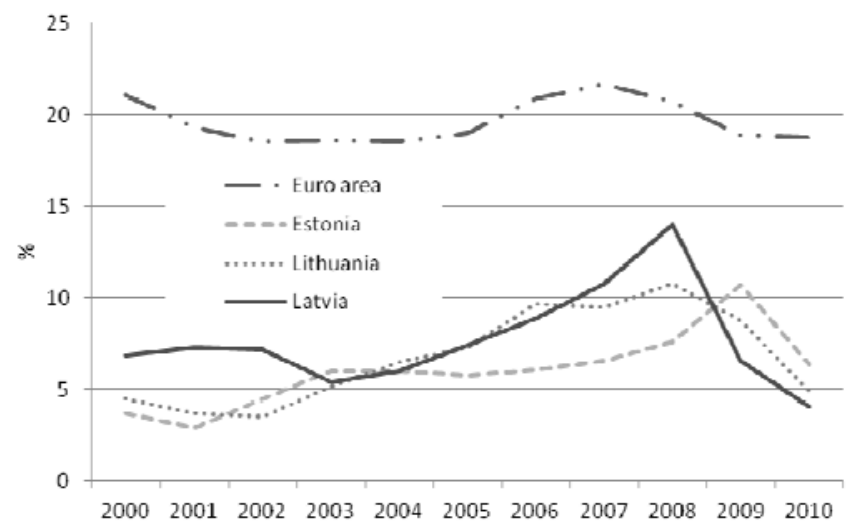

Fig. 1. Implicit tax rate on capital and business income of corporations, \%, Source: the European Commission.

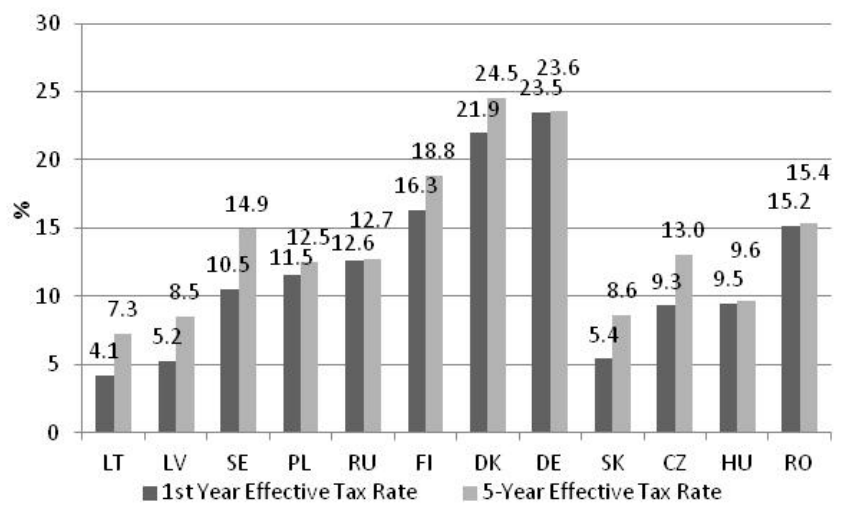

Fig. 2. Effective CIT rates for mid-sized company in 2004 in the Baltic Sea Region and CEE, \%, Source: [6, pp.59-60].

The effective CIT rate is considerably lower than nominal rate due to impact of numerous tax reliefs. This makes tax application more complicated adding some administrative burden on businesses and increases costs of tax collection as well. However, comparison of hours needed to comply with CIT administration with counterparts in the Baltic Sea Region and CEE shows that complexity of Latvian CIT system is on an average level in the region.

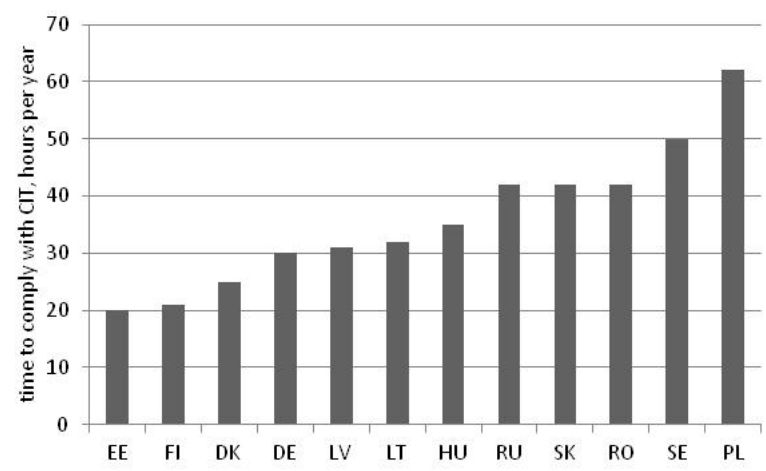

Fig. 3. Number of hours per year to comply with a corporate income tax, Source: [7, 120-123]. 
Investment flows suggest that Latvia is an attractive place for investment with gross fixed capital formation exceeding more than $30 \%$ of GDP and attracting a lot of foreign capital.

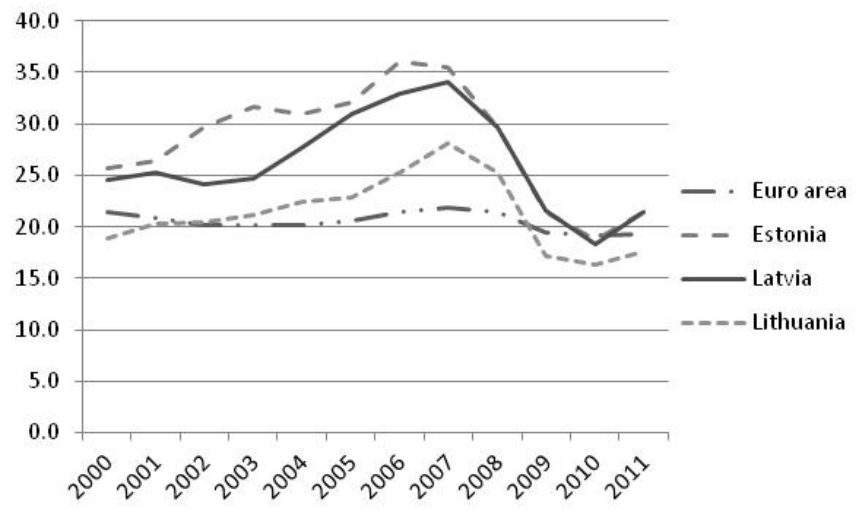

Fig. 4. Gross fixed capital formation, \% of GDP, Source: Eurostat.

This may mean that the existing corporate profit taxation is not an obstacle for investment and overall CIT regime is favourable for businesses.

However, by introducing different CIT reliefs the government aimed to achieve particular goals, e.g., development of export capable industries, especially manufacturing, regional cohesion, R\&D.

CIT law contains special favourable conditions for investment in equipment where manufacturing sector gains the most, but that does not materialize in relative position of this sector in economy. It even worsened during the boom period and started to recover only after the crisis but this growth is actually reflecting fundamental changes in underlying economic condition, which favour tradable sectors [8].

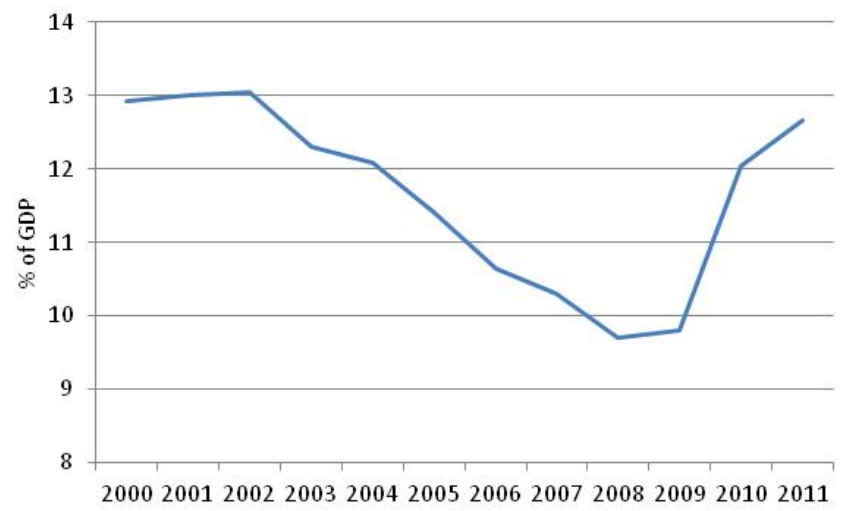

Fig. 5. Share of manufacturing in GDP. Source: the Central Statistical Bureau of Latvia.

Similar picture could be seen also regarding regional development where relative differences stayed almost stable despite the existing benefits to firms in the less developed regions.

These examples show that the existing tax reliefs help decrease a considerable tax burden and stimulate the growth of investment volume, but have little impact on promoting firms' investment targets.

One of the explanations is that actual gain through special tax reliefs was relatively small to affect market forces.

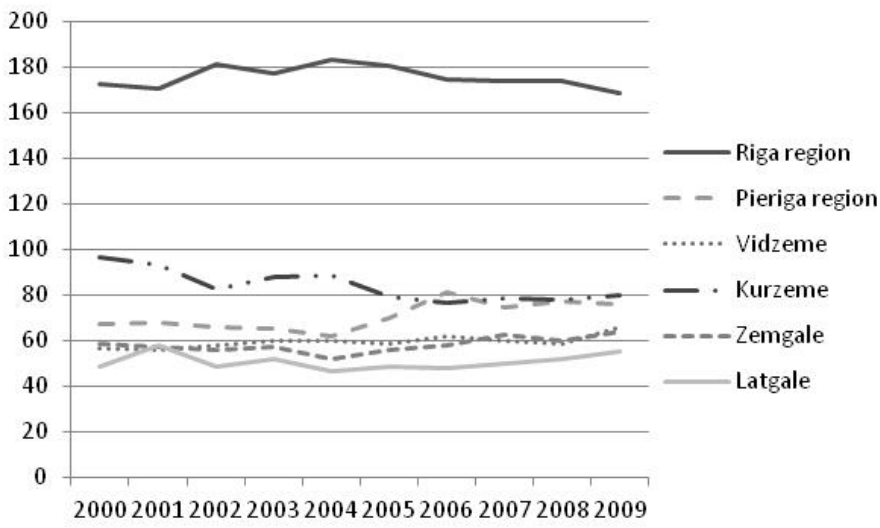

Fig. 6. GDP per capita in regions as \% of Latvian average, Source: the Central Statistical Bureau of Latvia, the author's calculation.

Tax relief for the acquisition of new production technology equipment, which is used mostly by manufacturing firms, allowed decreasing tax payments comparable just to $0.8 \%$ of gross value added of the whole manufacturing sector in 2011.

Tax reliefs oriented to businesses in the less developed regions amounted only to $0.06 \%$ of Latvian GDP excluding Riga region in 2009. Additionally, it could be stressed that most enterprises in regions build their economic activity by using the existing advantages - availability and price of labour, natural resources (wood, agricultural products etc.). Hence, tax relief for them plays a minor role in investment planning.

CIT reliefs for agriculture amounted to $2.2 \%$ of gross value added in the sector in 2011. For purposes of comparison, the state and EU subsidies to agriculture paid through the Rural Support Service of Latvia reached the amount comparable to $64.2 \%$ of gross value added in the sector. This shows that agriculture-related CIT reliefs are only a minor part of agriculture policy. Moreover, some of them were introduced long before Latvia joined the EU and its Common agriculture policy and have no connection with it.

There is a strong rationale for $\mathrm{R} \& \mathrm{D}$ tax provisions because of the existing positive externality. $[9,10]$ Latvia also introduced respective tax relief in 2009. The design of this tax relief, however, allows covering only part of R\&D investments (those associated with patents and trademarks), but this is done mostly to ensure proper administration of this tax relief and deter its usage in tax planning. In 2011, firms decreased their tax payments through this tax relief just by 5.6 thsd LVL. In 2011, Latvia was in last place in the EU Innovation Scoreboard $[10,7]$ suggesting that the government corrective action in this field would be necessary.

Special attention should be devoted to the tax reliefs for the financial sector. Establishing tax relief for reserves of financial intermediation companies is international practice, and it is justified by the specific character of business of financial companies and stability requirements by supervisory institutions. Therefore, this tax relief should be seen as reasoned. However, tax reliefs for stock trading initially were aimed at development of security market in Latvia. It was 
important to ensure reasonable turnover of stocks acquired by many people and companies during privatisation. Stock exchange was also seen as a potential place for corporation to attract capital. However, accession to the EU in 2004 ended favourable conditions for local shares. Modern communication technologies, globalisation and comparatively small capitalisation of domestic companies traded on stock exchange changed the spirit of this tax relief and made originally named goal out of reach. Therefore, this tax relief could be defined as obsolete and not consistent with the goals it had.

Main reason for the introduction of tax reliefs for shipping and aviation industries was in response to the international competition to ensure the existence of these industries in the Latvian jurisdiction. From this point of view, there are no losses from these incentives. After introduction of tonnage tax, registration of ships in Latvia increased, but still is at a low level. Most ships used in international transport and owned by Latvian companies are not registered in Latvia as taxes are not only reason to choose the flag. Tax relief for aircraft leasing takes into account the global nature of this industry and equitable availability of such services only outside the country.

The fiscal cost of these investment and sector oriented tax reliefs reached $185 \mathrm{mln}$ LVL in 2011, $196 \mathrm{mln}$ LVL in $2010^{2}$, and $107 \mathrm{mln}$ LVL in 2009 , which corresponds to $1.3 \%$ of GDP, $1.5 \%$ of GDP and $0.8 \%$ of GDP respectively. These figures are high if compared to CIT revenues. However, most of costs are related to the increased use of tax relief for reserves of financial intermediation companies because of impact of economic crisis on quality of their balance sheets.

Summarizing the analysis provided in this section, it can be concluded that tax reliefs oriented on specific investment activities, sectors or regions do not show satisfactory results. Reasons for this are associated with somehow exaggerated expectations by their introduction and actual possibilities to influence behaviour of investors through a corporate income tax in the case of Latvia. However, much depends on the design of tax relief and link with other economic policies. In addition, the historical aspects also play a role, as presented, is not terminated reliefs difficult to remove.

This analysis shows that in the areas, where CIT reliefs are used, there are large discrepancies in expectations and actual policy outcomes. This suggests that many CIT reliefs should be subjected to careful evaluation and possible change.

Based on the existing evidence and theoretical considerations, the author proposes a set of criteria that can be used to evaluate the existing or new tax incentives:

- Clear objective and relation to a general economic policy;

- Possibility to influence the objective it intends to achieve;

- Justification of positive externality;

- Budgetary costs and benefits compared to expenditurebased incentives;

${ }^{2}$ Calculation for 2010 does not include new tax reliefs that are in force since 2009 , as CIT declarations do not contain necessary information.
- Tax competition considerations (type of the taxable rent);

- Design:

o burden on an enterprise;

o burden on the tax administration;

0 possibilities of misuse.

- Rules of regular evaluation.

\section{CONCLUSIONS AND RECOMMENDATIONS}

Corporate income tax is an important source of revenues for governments and is widely used also as an economic policy tool.

Corporate income tax affects investment decisions by influencing an after-tax rate of return on investment.

Rate of corporate income tax is declining throughout the world and particularly in the European Union. This could be explained by the growing role of mobile capital flows in the global economy and tax competition for them.

Tax reliefs are widely used to offer smaller payments for particular activities, but do not influence the rest of tax base.

One of the main goals for introducing tax reliefs is to produce incentives for investment attraction in order to boost economic growth.

Latvian corporate income tax rate of $15 \%$ is one of the lowest in the EU. The law contains 23 tax reliefs, thus considerably decreasing an effective tax rate.

Implicit tax rate on business income of corporations in Latvia in 2010 was even $4.1 \%$. However, average ITR has been $8.3 \%$ since 2004 .

Nine tax reliefs of corporate income tax in Latvia are attributed to the promotion of investments. Additionally, six tax reliefs are aimed at supporting specific industries.

The existing tax reliefs help to considerably decrease tax burden but have little impact on promoting firms' investment behaviour.

In many cases, actual gain through special tax reliefs was relatively small to affect market forces. Examples of this are incentives for regional development, promotion of manufacturing and R\&D investments.

Design of tax relief also plays an important role in encouraging appropriate use and excluding unwanted tax planning activities. Design problems can be a reason for insignificant use of R\&D incentives.

The existing CIT system with the main overall investment incentives should be maintained. However, it is recommended examining and changing or removing special targeted tax reliefs, if necessary.

Policy goals and assumptions used by introducing or reexamining tax reliefs should be realistic and with line with overall country's economic policies.

The suggested criteria for such examination are the type of taxable rent, existence of positive externality, appropriate design and potential for tax planning, costs in revenue foregone, administrative burden (for both corporations and tax authorities). 


\section{REFERENCES}

[1] European Commission, Taxation trends in the European Union, Luxemburg, Publications Office of the European Union, 2012, 274 p.

[2] OECD, Policy Framework for Investment: A Review of Good Practices, Paris, OECD Publishing, 2006, 258 p

[3] Klemm Alexander, Causes, benefits, and risks of business tax incentives, International Tax and Public Finance, Vol.17 No 3, 2010, pp. 315-336. http://dx.doi.org/10.1007/s10797-010-9135-y

4] H.B. Polackova, M.A.C. Valenduc, L.Z. Swift, Tax ExpendituresShedding Light On Government Spending Through The Tax System: Lessons From Developed And Transition Economies (Directions In Development), Washington D.C., The World Bank, 2004, 245 p.

[5] I. Šņucins, E. Zarakovskis, I. Tiesnieks, Informatīvais ziņojums par pastāvošo uzñēmumu ienākuma nodokḷa atvieglojumu izvērtējumu no to efektivitātes un nodokḷu administrēšanas viedokḷa, Finanšu ministrija, 2011, 24 p., available at http://www.fm.gov.lv/lv/sadalas/nodoklu_ politika/ informativie zinojumi un petijumi/

[6] Simeon Djankov, Tim Ganser, Caralee McLiesh, Rita Ramalho, and Andrei Shleifer, The Effect of Corporate Taxes on Investment and Entrepreneurship, NBER Working Paper No. 13756, April 2009, 67 p.

[7] PwC and the World Bank Group, Paying Taxes 2012. The global picture, 2011, 130 p., available at www.pwc.com
[8] Kasjanovs, Igors. "Apstrādes rūpniecība Latvijā: joprojām nenovērtēta." Makroekonomika.lv. Latvijas Banka, 28.12.2011. available at http://makroekonomika.lv/node/4546

[9] Palazzi, Pamela, "Taxation and Innovation", OECD Taxation Working Papers, No. 9, OECD Publishing, 2011, p.78

[10] European Commission, Innovation Union Scoreboard 2011, 2011, p. 98

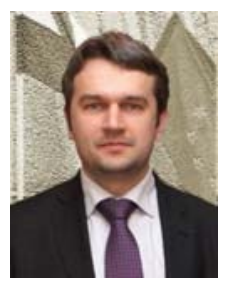

Ilmārs Šnucins received a Master's Degree in Business Administration from the University of Latvia, the Faculty of Economics and Management, 1999. The author is a doctoral student of the Doctoral Study Programme in Economics at the University of Latvia.

The author is a Head of the Tax Analysis Department at the Ministry of Finance of Latvia, 1 Smilsu Str., Riga, LV-1919. Previous positions were Deputy Head of the Department of Economic Analysis and Fiscal Policy and Head of the Macroeconomic Division at the Ministry of Finance of Latvia. The author is a Member of the Latvian Association of Econometricians. E-mail: snucins@hotmail.com

\section{Ilmārs Šṇucins. Uzṇēmumu ienākuma nodokḷa atvieglojumu efektivitāte investīciju veicināšanā Latvijā}

Uzņēmumu ienākuma nodoklis (UIN) tiek uzskatīts par vienu no galvenajiem šḳēešlliem investīcijām, jo tas ietekmē uzņēmumu faktisko (pēc nodokḷiem) investīciju atdevi. Neskatoties uz šādu teorētiski apstiprinātu atziṇu, visā pasaulē UIN paliek būtisks valstu budžetu ieñēmumu avots. Tomēr nodokḷu konkurence, lai piesaistītu mobilās kapitāla plūsmas, ir augsta, it īpaši Eiropā UIN nominālās un efektīvās likmes samazinās. Nodokļu atvieglojumi ir viens no instrumentiem, kas l̦auj mērḳēti samazināt nodokḷu slogu atsevišksām darb̄̄bām, neietekmējot pārējo nodokḷu bāzi. N̦emot vērā sagaidāmos pozitīvos ārējos efektus, Latvijas UIN likums piedāvā virkni atvieglojumu, kas vērsti uz investīcijām un atsevišşku nozaru attīstības veicināšanu. Raksta mērķis ir izpētīt UIN atvieglojumu teorētisko pamatojumu, izvērtēt esošo Latvijas UIN investīciju veicinošo atvieglojumu efektivitāti, sniegt priekšlikumus atvieglojumu izvērtēšanas kritērijiem un to uzlabošanas rekomendācijas. Raksta metodologija balstās uz zinātniskās literatūras un likumdošanas izpēti, kā arī makroekonomisko un nodokḷu datu analīzi. Pamatojoties uz veikto analīzi, secināts, ka kopumā deviṇi UIN atvieglojumi ir paredzēti specifisku vai vispārēju investīciju veicināšanai, bet seši atbalsta ieguldījumus konkrētās nozarēs. Tas palīdz būtiski samazināt UIN efektīvo likmi un uzlabo Latvijas pozīciju starptautiskajā konkurencē par investīcijām. Tomēr atvieglojumi minimāli ietekmē uzṇēmumu uzvedību, izvēloties investīciju veidu, reǵionu vai nozari, ko valsts ir noteikusi par mērḳi, ieviešot konkrētus atvieglojumus. Pamatā to nosaka divi faktori - nodokḷu atvieglojumu sniegtais atbalsts ir pārāk mazs, lai ietekmētu tirgus varu, un nepiemērota atvieglojumu konstrukcija. Autors izsaka priekšlikumu, ka esošie vispārēja rakstura investīciju atvieglojumi ir saglabājami, bet speciālie, mērksētie, atvieglojumi ir jāizvērtē un atbilstoši vērtējumam ir jāmaina vai jāatceḷ. Ieteiktie vērtēšanas kritēriji ir reālistisku, valsts ekonomiskajai politikai atbilstošu mērḳu izvirzišana, apliekamās rentes tips, pozitīvu ārējo efektu esamība, piemērota konstrukcija un potenciāls nevēlamai nodokḷu plānošanai, nodokḷu ien̦ēmumu zaudējums un administratīvais slogs.

Илмарс Шнюцинс. Эффективность налоговых льгот в применении подоходного налога с предприятий как поощрение инвестирования в Латвии

Подоходный налог с предприятий (ПНП) считается одним из главных препятствий для инвестиций, так как он оказывает влияние на фактическую (после уплаты налогов) прибыль предприятий от инвестиций. Несмотря на такую теоретически общепризнанную установку, ПНП во всем мире остается важным источником доходов государственного бюджета. Все же налоговая конкуренция, направленная на привлечение мобильного капитала, очень высока, и под влиянием этого, особенно в Европе, номинальные и фактические ставки подоходного налога с предприятий снижаются. Налоговые льготы - один из инструментов, который позволяет целенаправленно снизить налоговое бремя на отдельные виды деятельности, не оказывая влияния на остальную налоговую базу. Принимая во внимание ожидаемый позитивный внешний эффект, латвийский закон о ПНП предлагает несколько налоговых льгот, способствующих инвестициям и развитию отдельных отраслей. Цель данной статьи - исследовать теоретические основы налоговых льгот ПНП, оценить эффективность налоговых льгот ПНП, способствующих инвестициям в Латвии, внести предложения по критериям оценки эффективности налоговых льгот и рекомендации по их улучшению. Методология статьи основывается на исследованиях научной литературы и законодательства, а также на анализе макроэкономических и налоговых данных. Основываясь на данный анализ, можно сделать вывод, что в общем объеме девять видов налоговых льгот ПНП направлены на поддержку общих или специфических инвестиций, а шесть видов налоговых льгот способствуют вложениям в конкретных отраслях. Это помогает существенно снизить эффективную ставку ПНП и улучшает позиции Латвии в международной конкуренции по инвестициям. Но в то же время налоговые льготы минимально воздействуют на политику предприятий, выбирая вид, регион или отрасль инвестирования, которые государство считает приоритетными при введении конкретных налоговых льгот. В-основном, это определяют два фактора - эффект от налоговых льгот слишком мал, чтобы повлиять на рыночные механизмы, и неподходящая конструкция применения налоговой льготы. Автор статьи предлагает, что существующие общие налоговые льготы на инвестиции можно сохранить без изменений, а специальные, целевые налоговые льготы необходимо оценить и соответственно оценке внести изменения или отменить. Предложенные критерии оценки - постановка реалистичных, соответствующих государственной экономической политике целей; тип облагаемой ренты; существование позитивного внешнего эффекта; подходящая конструкция и потенциал нежелательному налоговому планированию, потеря налоговых доходов и административные сложности. 